UDC 373.2.015.31:78

DOI: https://doi.org/10.31470/2415-3729-2020-12-128-144

\title{
Development of Preschoolers' Musical Abilities by Means of the K. Orff's Method: Theoretical Aspects
}

\section{Oksana Mkrtichian}

Doctor of Philosophy in Pedagogy (Ph.D), Associate Professor, Doctoral student of the Department of Pedagogy, H. S. Skovoroda Kharkiv National Pedagogical University, $\square 29$, Alchevsky str., Kharkiv, Ukraine, 61002

E-mail:mkrtichan79@gmail.com ORCID: http://orcid.org/0000-0003-4962-3631

Date of receipt of the article: September 28, 2020 Article accepted for publication: November 22, 2020

\section{Розвиток музичних здібностей дошкільників засобами методу К. Орфа: теоретичні аспекти}

\section{Оксана Альбертівна Мкртічян}

кандидат педагогічних наук, доцент докторант кафедри педагогіки, Харківський національний педагогічний університет імені Г. С. Сковороди

вул. Алчевських, 29, м. Харків, Україна, 61002

Дата надходження статті: 28 вересня 2020 p. Стаття прийнята до друку: 22 листопада 2020 р.

\section{Abstract}

The article reveals the problem of forming a comprehensively developed child's personality by means of 
musical art. The development of the child, his or her formation as a person is a significant problem of preschool education. One of the ways to achieve this goal is to involve children in the process of music education, which has a great impact on child development. The purpose of the article is to reveal the influence of the Karl Orff's concept of music education on the preschoolers' musical abilities. Research methods at the scientific and theoretical level include: method of analysis - the analysis of scientific and methodological literature, methods of teaching music, methods of synthesis and generalization; system analysis - to display the basic components of the methodology.

The results. On the basis of the conducted analysis, the principles of the pedagogical approach of Karl Orff and features of aesthetic education of children in the conditions of the given system were defined. Since preschool education requires new approaches in the context of the development of preschoolers by means of musical art, it is advisable to introduce the K. Orff's method in the educational process of preschool institution. Moreover it is proved that the presence of music in the educational process opens opportunities for the harmonious development of preschool children. K. Orff's musical and pedagogical approach is a concentrated carrier of the ideas of humanistic pedagogy, pedagogy of the freedom of creative personality.

Conclusions. K. Orff's method is spreading and influencing the music education of Ukraine, involving Ukrainian culture in the educational process, using folk and children's songs, elementary music, which is an act of elementary self-expression, to which man is adapted by nature. Consequently, the K. Orff's methods is universal, flexible and open, which allows us to combine its principles with various methods of music education, which is spread and successfully used in preschool institution; and the creation of special pedagogical conditions, the use of aesthetic techniques and musical means in the classroom with the active participation of children helps them to keep the dominance of positive emotions, significantly increases motivation for 
learning and music, has an effective impact on motor, speech, communication and psychological development.

Keywords: musical education, creativity, musical abilities, playing music, the K.Orff's method.

\section{References:}

1. Apraksina O.A. (1983). Metodika muzykal'nogo vospitaniya $v$ shkole [Methods of musical education at school]. Москва : Prosveshcheniye [in Russia].

2. Barenboym L. A. (1978). Elementarnoye muzykal'noye vospitaniye po sisteme Karla Orfa [Elementary music education according to the system of Karl Orff]. Москва : Sovetskiy kompozitor [in Russia].

3. Zatsepina M. B. (2009). Rol' N. A. Vetluginoy i A. V. Keneman v stanovlenii i razvitii teorii khudozhestvennogo i esteticheskogo vospitaniya deteyt [The role of N. A. Vetlugina and $\mathrm{A}$. V. Keneman in the formation and development of the theory of artistic and aesthetic education of children]. Sovremennoye doshkol'noye obrazovaniye: teoriya i praktikaModern preschool education: theory and practice. 5. 23-25 [in Ukraine].

4. Oleksyuk O. (2006). Muzychna pedahohika [Musical pedagogy]. Kyiv : KNUKiM [in Ukraine].

5. Padalka H. (2008). Pedahohika mystetstva (teoriya $i$ metodyka vykladannya mystets'kykh dystsyplin) [Pedagogy of art (theory and methods of teaching art disciplines)]. Kyiv: Osvita Ukrayiny [in Ukraine].

6. Rostovs'kyy O. (2011). Teoriya i metodyka muzychnoyi osvity [Theory and methods of music education]. Ternopil': Navchal'na knyha - Bohdan [in Ukraine].

7. Rudnytska O. (2002). Pedahohika; zahalna ta mystetska [Pedagogy: general and artistic]. Kyiv: Education [in Ukraine].

8. Rytsareva M. G. (2006). Muzyka i ya. Populyarnaya entsiklopediya dlya detey [Music and me. Popular encyclopedia for children]. Moskva : Muzyka [in Russia]. 
9. Savchenko, R. A. (2014). Teoriya i metodyka formuvannya muzychno-pedahohichnoyi kompetentnosti maybutnikh vykhovateliv ta muzychnykh kerivnykiv DNZ [Theory and methods of formation of musical and pedagogical competence of future educators and musical directors of children's institutions]. Extended abstract of Doctor's thesis. Kyiv : National Pedagogical Dragomanov University [in Ukranian].

10. Folomyeyeva, N. A. (2001). Pedahohichni tekhnolohiyi estetychnoho vykhovannya ditey vikom 5-10 rokiv zasobamy muzychnoho mystetstva [Pedagogical technologies of aesthetic education of children aged 5-10 by means of musical art]. Extatnded abstract of candidate's thesis. Kyiv: The Institute of Problems on Education of the National Academy of Educational Sciences of Ukraine [in Ukrainian].

\section{Вступ}

Особливо актуальними в сучасних умовах $є$ проблема розвитку музичних здібностей дітей та акцент на всебічний розвиток дитини та її соціалізацію. У сучасному суспільстві такі поняття, як «творчий підхід», «креативність», «музичний потенціал» є показниками професіоналізму. У зв'язку з цим до вихователів ЗДО висуваються високі вимоги, які повинні будувати освітній процес таким чином, щоб не тільки враховувалися здібності та можливості дошкільників, а й здійснювався максимальний розвиток їх особистості.

Вивченням питань дошкільного музичного виховання та проблемами розвитку музичних здібностей дітей займалися такі вчені-педагоги, як О. Апраксіна (Апраксіна, 2006), А. Ветлугіна (Зацепіна, 2009: 23-25), Н. Фоломєєва (Фоломєєва, 2001), Г. Падалка (Падалка, 2008), О. Олексюк (Олексюк, 2006), О. Ростовський (Ростовський, 2011), С. Сисоєва (С. Сисоєва, 1994. 112 с.), Р. Савченко (Савченко, 2014), О. Рудницька (Рудницька, 2002).

Мета статті - розкрити вплив концепції музичного виховання Карла Орфа на музичні здібності дошкільників. 
Актуальність статті зумовлена перспективністю використання методу музичного виховання Карла Орфа в ЗДО та недостатнім рівнем опанування даним методом сучасних вихователів та студентів факультетів дошкільної освіти.

\section{Матеріал і методи досліджень}

3 посиланням на науково-методичну літературу, в якій існує велика кількість визначень поняття «музичні здібності», які формуються та розвиваються в певних умовах музичної діяльності, в процесі взаємодії вихователя та дитини, що передбачає застосування певних методів і засобів навчання. Методи дослідження на науково-теоретичному рівні включали в себе: метод аналізу - аналіз науковометодичної літератури, методики викладання музики, методи синтезу та узагальнення. Системний аналіз застосовувався для відображення базових складових методики. Науковці неоднозначно підходять до розуміння суті поняття «здібності». Більшість дослідників вважають, що здібності не зводяться до знань, умінь і навичок, однак забезпечують їх швидке набуття, закріплення й ефективне використання в практичній діяльності. Визначення умов, що включають: компетентність музичного керівників, вихователів, педагогів; застосування традиційних та нових методів і прийомів музичного виховання, спеціально обладнане естетичне середовище музичної зали.

\section{Результати та їх обговорення}

Музично-педагогічна концепція К. Орфа в цілому $є$ концентрованим носієм ідей гуманістичної педагогіки. Гуманістична педагогіка в сучасному пї розумінні - це педагогіка свободи творчої особистості. Ідеї цієї педагогіки все своє життя сповідував Карл Орф, який отримав уявлення про неї ще за часів навчання в класичній гімназії, де його улюбленими предметами були стародавні мови та хоровий спів. 
Доцільно зазначити про те, що при створенні педагогічної концепції на К. Орфа вплинули ідеї I. Песталоцці та К. Сакса, які грунтуються на основах педагогіки та елементарної музики. Музика $є$ засобом раннього виховання дитини, сприяє творчому її розвитку.

У XX столітті інтерес до простого, елементарного проявився не тільки в педагогіці, а й в мистецтві: в музиці (К. Орф, Б. Барток, П. Хіндеміт, 3. Кодаї), в живописі (В. Кандинський, Ф. Марк).

Так, прагнення до простоти знайшло відображення й в творчості самого К. Орфа, а саме звернення до простих засобів музичної мови, іiі «праелементів»: вокальному одноголоссю, діатоніці, паралельного руху голосів, різноманітним проявам остинато в гармонії, ритмі, фактурі.

Початок композиторським пошукам було покладено в перших зошитах Шульверка - робоча книга, яка певною мірою стала полем для творчих експериментів. Музичнопедагогічна концепція К. Орфа, названа ним «Шульверк. Музика для дітей», формувалася поступово упродовж тридцяти років (20-50 роки XX століття). В історії іiі становлення простежуються певні етапи, які відображають основні положення концепції. Вона складалася із спроб осучаснення К. Орфом історичної спадщини минулого, використання ідей прогресивної педагогічної думки початку XX століття, відкриттів етномузикознання в галузі неєвропейських музичних культур, власної емпіричної педагогічної практики та композиторської творчості. Так, запозичені не тільки деякі прийоми й засоби, а й інструменти як носії певних звукорядів, ладів і тембрів (різновиди ксилофонів і екзотичних ударних інструментів). К. Сакс, музикознавець-етнограф, відомий знавець і експерт в галузі інструментів народів світу, консультував К. Орфа щодо питань пов’язаних з музикуванням у різних народів.

Отже, в своєму теоретичному обгрунтуванні щодо поняття «елементарна музика» музикант спирався на 
дослідження порівняльного музикознавства. Складові елементарного - це первинні, корінні, неподільні елементи.

Музична культура українського народу бере свої витоки та спирається, в першу чергу, на національний фольклор, зокрема й дитячий, який є частиною різноманітної народної культури. Найважливіший за своєю духовною цінністю дитячий фольклор створює підставу для початкового музичного виховання маючи різноплановість і оригінальність знайомих усім жанрів: це потішки, примовки, лічилки, дражнилки, заклички, хороводи, ігрові пісенні приспіви, а також великий розділ календарних пісень, що дійшли до нас 3 часів язичництва. Жанри дитячого фольклору, особливо календарно-обрядові пісні, інтонаційно та змістовно схожі, що дозволяє дітям швидко запам'ятовувати й довго зберігати їх в пам'яті. У своєму розмаїтті дитячий фольклор досить архаїчний: нескладно виявити очевидні спільні елементи, типові ознаки, які не залежать від національних рис. Це дозволяє широко використовувати в музичному вихованні дитячий фольклор.

Тому, в основу своєї педагогічної концепції К. Орф поклав етнографічні форми музикування доступні до переживання в дитячому віці й відповідної психіці дитини: елементарне музикування доступно всім і не залежить від спеціальної освіти, тому що $\epsilon$ актом елементарного самовираження (природне для дитини), є фундаментом для подальшого музичного виховання особистості й закладає основи для її різнобічного розвитку.

Елементарна музика призначається не для відтворення, а для творчого самовираження дітей. К. Орф пропонує творити не тільки дитині, але й дорослому, надаючи вибір методики самому педагогу, дотримуючись таких принципів:

1. Самостійне створення дітьми музики та руховому супроводу.

2. Група дітей складається 3 двох учасників, у кожного рівноправна участь у відтворенні або імпровізації, однак кількість учасників групи не обмежена. 
3. Свобода дітей на заняттях у вираженні емоцій: плескати, топати, рухатися.

4. Велика увага на заняттях до диригування, щоб кожна дитина мала можливість керувати виконанням.

5. Ритмування текстів (імена, лічилки, найпростіші дитячі пісні). Виховання відчуття гармонійності та стрункості рідної мови.

6. Розуміння імпровізаційних шляхів (інтонація), перехід від ладової конструкції до пентатоніки.

7. Музикування в межах п'ятиступеневого звукоряду, потім - семиступеневого звукоряду.

8. Навчання дітей грі на простих музичних інструментах з відчуттям радості й успіху.

Крім того, навчаючи дітей елементарному музикуванню, створюється інструментарій. Варто відзначити, що в українській народній культурі є особливі галузі, де використання інструментів було прийнято 3 давнини (культура скоморохів, дитячий фольклор). Скоморохи грали на найрізноманітніших інструментах (сопілки, гуслі, ріжки, різні брязкальця, тріскачки, дзвіночки). Інструментальна музика звучала в їх виконанні як самостійно, так і була супроводом театральних вистав, танців і хороводів. Барвистість, яскравість уявлень завжди приваблювала дітей. Крім того, в дитячому фольклорі також існують спеціальні інструментальні жанри: награвання та сигнали. Дитячі музичні інструменти, переважно духові, зроблені з природного матеріалу, всілякі різновиди свистків, дудочок.

Отже, імпровізація, музикування в поєднанні 3 пластичним мистецтвом, дитячі пісні, п'єси та вправи, що сприяють розвитку музичних і творчих здібностей, лежать в основі педагогічної системи К. Орфа.

Зазначимо, що здібності - це індивідуальні психофізіологічні особливості людини, що характеризуються швидкістю, глибиною, легкістю й міцністю оволодіння будь- 
якою діяльністю, є гарантом їі успішності. Зазвичай види здібностей розрізняють за їх спрямованістю, або спеціалізацією. Так, виділяють загальні здібності (індивідуальні властивості особистості, що забезпечують якість i ефективність оволодіння будь-якими видами діяльності) та спеціальні (особистісні властивості, що допомагають досягти найвищої результативності в певній сфері діяльності) (Олексюк, 2006). Поняття «здібності» $є$ складовою поняття «творчість», причому здібності можуть бути не реалізовані, а творчість завжди має який-небудь продукт - матеріальний або ідеальний, який, є цінним для суспільства, з одного боку, і цінним для суб' єкта творчості, 3 іншого, з вираженим ступенем реалізації особистості, а музичні здібності розглядаються як індивідуальні психологічні властивості людини, що зумовлюють сприйняття, виконання, створення музики (Олексюк, 2006).

Нині доцільно застосовувати тренінги з орф-педагогіки з майбутніми вихователями ЗДО, в процесі яких учасники можуть обмінюватися ідеями та демонструвати технічні прийоми, знайомитися 3 першоосновами музики, звуку, поєднуючи з рухом, сценічною виразністю, театром, грою. Такий підхід враховує особливості дитячої психології, комфортний психолого-педагогічний клімат класичного заняття передбачає рух і музикування на орф-інструментах (ударні інструменти, ксилофони тощо), розвивається мовлення, комунікативні здібності, увага, концентрація, моторика.

Залучення дошкільника до музичного мистецтва, розвиток індивідуально-творчих сил, музикальності $\epsilon$ основним призначенням методики К. Орфа. Саме в цей період дитині необхідно надати можливості для емоційного розвитку, що включають в себе досвід чуттєвості та виховання здатності контролювати вираз почуття. Все, що відчуває дитина в цьому віці, все те, що прокинулося в неї в цей період, стає визначальним чинником всього подальшого 
життя. Так, одним із складників музичного розвитку дитини є пісня. Педагоги підбирають пісні відповідно до специфіки свого предмета. Саме такі проспівані вірші допомагають вивчати необхідні компоненти навчальної програми.

Нині в Україні велика кількість педагогів, вихователів, які мають реальне уявлення про принципи роботи з дітьми в процесі імпровізації. Педагогіка К. Орфа передбачає, що кожна людина з фаховою освітою, яка працює за принципами Шульверка, що є співавтором К. Орфа: розвиває, доповнює i адаптує «буквар елементарної музики». До такої роботи потрібно мати власне внутрішнє прагнення, тільки тоді вона буде плідною та результативною.

Загальновідомо, що будь-який новації повинно бути знайдено відповідне місце, де вона буде повноцінно й ефективно взаємодіяти зі сформованими традиціями, допомагаючи вирішувати педагогічні завдання, оновлювати педагогічний процес. Таким чином, майбутній вихователь ЗДО, який прагне навчитися працювати з дітьми за методом К. Орфа, зустрінеться 3 необхідністю самостійно організовувати навчальний процес, виходячи з можливостей і потреб кожної конкретної групи дітей або окремої дитини. Майбутній вихователь повинен адаптувати метод Орфа до упровадження його для розвитку дітей в ЗДО.

Тому, більшість педагогів, які працюють за програмою «Шульверк» мають власні цікаві моделі для музикування, створені разом 3 дітьми в процесі занять. Обмін цими моделями та новітніми ідеями в галузі творчого навчання та дитячої музичної педагогіки становить основний зміст практичних семінарів, форумів, конференцій.

В програмах майбутніх вихователів ЗДО повинні ставитися завдання щодо створення авторських розробок на основі принципів Шульверка К. Орфа. Перевагою таких програм $\epsilon$ визначення цілей (пошук нових шляхів спілкування вихователя та дитини; розвиток у дошкільника природних здібностей), а також завдань (навчити дитину 
володіти своїм голосом, будь-яким дитячим музичним інструментом, тілом), прагнення визначити етапи музичного розвитку дитини, планування занять мовленнєвими іграми та вправами.

Слід зазначити, що при традиційному стилі проведення музичних занять, особливо для дітей дошкільної ланки, дітям не вистачає емоційного виплеску, вільного творчого самовираження - рухового, інструментального, драматичного. Існуюча програма орієнтує на музикознавчу сторону освоєння дисципліни, що властиво професійному навчанню. Традиційна музична освіта, спираючись на сприйняття й пам'ять, призводить до штучної інтелектуалізації, майже не залишаючи місця для уяви, інтуїції, почуття, розвитку творчих здібностей. Подібне навчання позбавляє дитину природних потреб в русі, полісенсорних відчуттів, радості, можливості та права на помилку, готує особистість відтворювати або міркувати, але не творити. Тим часом важливість духовно-морального, творчого розвитку дітей ще в двадцяті і тридцяті роки XX століття підкреслювали відомі вчені-просвітителі в галузі музики Б. Яворський та Б. Асаф’єв. Вони шукали не тільки методичні прийоми навчання, скільки способи до впровадження «глибоко цінного принципу імпровізації», стимули, що спонукають дітей до творчості. Такими стимулами є вміння слухати музику, поєднувати в різних послідовностях музично-інтонаційні обороти, продумувати звуко-мовленнєві фарби, спостерігати за ритмом рухів людей, складати мелодію на певний літературний текст, грати в ансамблі на найпростіших інструментах (барабани, бубни тощо), тобто педагоги пропонували використовувати найпростіше музикування - «елементарну музику» за К. Орфом (Баренбойм, 1978).

Так, використання музикування, зокрема й домашнього, як форми дозвілля в роботі з дітьми, передбачає комплексне використання мови як основи роботи над 
ритмом, рухом, гри на шумових (народних) інструментах (різні види імітацій, варіацій, ритмічні рондо).

Популярна енциклопедія для дітей трактує «музикування» як показник музичної культури суспільства та культури взагалі, нарівні з читанням, заняттям поезією, участю в аматорських театральних постановках, малюванням, рукоділлям тощо. 3 будь-яким активним залученням до мистецтва через власну творчість незалежно від того, професійне воно або аматорське (Рицарева, 2006). В галузі музичної педагогіки з' явилося наступне визначення музикування, а саме: це колективна або індивідуальна різноманітна музична діяльність індивідуумів, заснована на музичних i життєвих враженнях, що визначається внутрішньою потребою спілкування 3 музикою, яка $\epsilon$ творчим самовираженням і розвитком.

Вчені відзначають, що елементарне музикування доступно всім і не залежить від спеціальної освіти, є актом елементарного самовираження, до якого людина пристосована самою природою.

Автор педагогічної концепції елементарного музикування відзначав, елементарне музикування доступно всім і не залежить від спеціальної освіти, тому що є актом елементарного самовираження, притаманне людині від самої природи. Музика поряд 3 елементарними формами руху, словесними текстами є рівноправним компонентом і засобом об'єднання основ культури. К. Орф відзначав, що елементарне музикування - це не музика, пов'язана з рухом, танцем, словом, ii потрібно самому створювати, долучатися до неї як слухачеві, так і учаснику (Баренбойм, 1978).

Сучасна педагогічна концепція К. Орфа характеризується комплексним розумінням людини, його історії, середовища, генетичних законів i відсутністю насильства над природою дитини.

Концепція будується на:

- поєднанні музики, руху й мови, яка виключає можливість перевтоми, емоційної статичності, гіподинамії; 
- творчості, розвиваючої здатності знаходити нетрадиційні, різноманітні підходи до музичного мистецтва; - спілкуванні, вираженому в співтворчості, співпереживання суб'єктів освітнього процесу.

Специфіка елементарного музикування полягає в тому, що воно, з одного боку, враховує психологічні особливості, індивідуальні нахили дітей, з іншого-сприяє розвитку всіх життєвих функцій: спілкування, мова, рух тощо.

Навчанні техніки гри на музичних інструментах повинна передувати гра жестами або рухами (удари, клацання, ляпаси, притупування). Такі заняття розвивають музичний ритм, збагачують сенсорний та тактильний досвід дітей. Інструментальна гра в залежності від програмного матеріалу може супроводжуватися співом, рухами або вправами, що вигадують діти в межах теми уроку. Володіючи прийомами гри на інструментах, діти «створюють свою музику», свій неповторний акомпанемент. Такі імпровізації не слід розглядати як твори, призначені для концертного виконання. Це моделі, які надають поштовх дитячій фантазії, творчого мислення. Причому в даних ситуаціях творить i керівник, вибираючи тактику, способи мотивації дошкільнят до спільної діяльності, до освоєння предмету.

У різних видах музичної діяльності $\epsilon$ саморобні елементарні музичні інструменти (дзвінки тощо), А також театральні атрибути, декорації, виготовлені дітьми та їх батьками, вихованці фантазують, створюють сюжет, хоровод або народні ігри. Майстерність фахівця виражається в тому, щоб непомітно для дітей ставити їх в позицію дослідників, першовідкривачів нових музичних понять і термінів.

В умовах «тотальної» творчості у дітей підтримується позитивний емоційний тонус, реалізується природна потреба в руховій активності, спілкуванні один з одним, з'являється бажання висловити своє ставлення до музики. 
Застосування елементарного музикування дозволяє без витрат додаткового часу проводити діагностику не тільки музичного, але й емоційного, рухового, мовленнєвого, комунікативного розвитку дитини. У музичній діяльності, де кожна дитина підбирає собі роль за інтересами (спів, мова, танець, інструментальна гра), вихователь має можливість спостерігати та фіксувати розвиток моторної сфери, комунікативних навичок, координацію рухів, мовлення тощо.

\section{Висновки}

Отже, загальна музична освіта існує вже більше ста років і накопичила величезний досвід. Специфіка методу Орфа полягає в проведенні дітей через всі стадії розвитку європейської музичної культури, що дозволяє згодом долучитися до висот класичної музики. Педагогічні принципи К. Орфа прийняті в багатьох країнах, не тільки європейських, в США, Канаді, а й в країнах Південної Америки, Японії, Китаю. Основними ідеями творчої музичної педагогіки за методом Орфа $\epsilon$ : розвиток позитивного сприйняття музичного мистецтва дитиною та розвиток іiі музичних здібностей; підготовка слухача до спілкування з музичною культурою в цілому за допомогою вивчення законів елементарної музики. Метод К. Орфа певною мірою поширюється та певною мірою впливає на музичну освіту України, залучаючи українську культуру в освітній процес, використовуючи народні й дитячі пісні в якості фактичного матеріалу, поєднуючи їх 3 методом К. Орфа та створюючи нові навчальні матеріали. Концепція К. Орфа є універсальною, гнучкою та відкритою, що дозволяє поєднувати іï принципи з різними методиками музичного виховання й освіти, що поширюється та успішно застосовується в ЗДО.

Учені також відзначають, що створення спеціальних педагогічних умов, використання естетичних прийомів $\mathrm{i}$ музичних засобів на заняттях при активній участі самих дітей сприяє підтримці у них домінанти позитивних емоцій, значно підвищує мотивацію до навчальної та музичної діяльності, 
надає дієвий вплив на руховий, мовленнєвий, комунікативний і психологічний розвиток.

\section{Література}

1. Апраксина О. А. Методика музыкального воспитания в школе. Москва : Просвещение, 1983. 224 с.

2. Баренбойм Л. А. Элементарное музыкальное воспитание по системе Карла Орфа. Москва : Советский композитор, 1978. 360 с.

3. Зацепина М. Б. Роль Н. А. Ветлугиной и А. В. Кенеман в становлении и развитии теории художественного и эстетического воспитания детей. Современное дошкольное образование: теория и практика. 2009. № 5. С. 23-25.

4. Олексюк О. Музична педагогіка. Київ: КНУКіМ, 2006. $188 \mathrm{c}$.

5. Падалка Г. Педагогіка мистецтва (теорія $i$ методика викладання мистецьких дисциилін). Київ : Освіта України, 2008. 274 c.

6. Ростовський О. Теорія і методика музичної освіти. Тернопіль: Навчальна книга - Богдан, 2011. 640 с.

7. Рудницька О. Педагогіка: загальна та мистецька. Київ: Освіта, 2002. 270 с.

8. Рыцарева М. Г. Музыка и я. Популярная энцииклопедия для детей. Москва : Музыка, 2006. 367 с.

9. Савченко Р. А. Теорія і методика формування музичнопедагогічної компетентності майбутніх вихователів та музичних керівників ДНЗ : автореф. дис. ... д-ра пед. наук : 13.00.02. Національний педагогічний університет імені М. П. Драгоманова. Київ, 2014. 40 с.

10. Фоломєєва Н.А. Педагогічні технології естетичного виховання дітей віком 5-10 років засобами музичного мистецтва : автореф. дис. ... канд. пед. наук : 13.00.07. Інститут проблем виховання НАПН України. Київ, 2001. 22 c. 
Мкртічян О. А.

\section{Розвиток музичних здібностей дошкільників засобами методу К. Орфа: теоретичні аспекти}

\section{Анотація}

У статті розкрито проблему формування всебічно розвиненої особистості дитини засобами музичного мистецтва. Розвиток дитини, становлення їі як особистості значна проблема дошкільної освіти. Одним із шляхів реалізації цієї мети є залучення дітей до процесу музичного виховання, яке має великий вплив на розвиток дитини. На основі проведеного аналізу визначено принципи педагогічної концепції Карла Орфа та особливості естетичного виховання дітей в умовах даної системи. Оскілки дошкільна освіта вимагає нових підходів в контексті розвитку дошкільника засобами музичного мистецтва, доцільним є упровадження методу Орфа в освітній процес ЗДО. Доведено, що наявність музики в навчально-виховному процесі відкриває можливості для гармонійного розвитку дітей дошкільного віку.

Мета статті - розкрити вплив концепції музичного виховання Карла Орфа на всебічний розвиток дошкільників. Методи дослідження на науково-теоретичному рівні включають в себе: метод аналізу - аналіз науково-методичної літератури, методики викладання музики, методи синтезу та узагальнення. Системний аналіз застосовувався для відображення базових складових методики.

Музично-педагогічна концепція К. Орфа $\epsilon$ концентрованим носієм ідей гуманістичної педагогіки, педагогіки свободи творчої особистості.

Метод К. Орфа в поширюється та впливає на музичну освіту України, залучаючи українську культуру в освітній процес, використовуючи народні й дитячі пісні, елементарного музикування, що $є$ актом елементарного самовираження, до якого людина пристосована самою 
природою. Концепція К. Орфа є універсальною, гнучкою та відкритою, що дозволяє поєднувати іiі принципи з різними методиками музичного виховання й освіти, що поширюється та успішно застосовується в ЗДО.

Ключові слова: музична освіта, творчість, музичні здібності, музикування, метод Орфа.

\section{Мкртичян О. А}

\section{Развитие музыкальных способностей дошкольников средствами метода К. Орфа: теоретические аспекты}

\section{Аннотации}

В статье рассмотрена проблема формирования всесторонне развитой личности ребенка средствами музыкального искусства. Развитие ребенка, становление его как личности - большая проблема дошкольного образования. На основе проведенного анализа выделены принципы педагогической концепции Карла Орфа и особенности эстетического воспитания детей в условиях данной системы. Доказано, что наличие музыки в учебно-воспитательном процессе открывает возможности для гармоничного развития детей дошкольного возраста.

Цель статьи - раскрыть влияние концепции музыкального воспитания Карла Орфа на всестороннее развитие дошкольников. Методы исследования на научнотеоретическом уровне включают в себя: метод анализа анализ научно-методической литературы, методики преподавания музыки, методы синтеза и обобщения.

Метод К. Орфа в распространяется и влияет на музыкальное образование Украины, привлекая украинскую культуру в образовательный процесс, используя народные и детские песни, элементарного музицирования.

Ключевые слова: музыкальное образование, творчество, музыкальные способности, музицирование, метод Орфа. 